$\begin{array}{ll}\text { Abstracta Iranica } & \begin{array}{l}\text { Abstracta Iranica } \\ \text { Revue bibliographique pour le domaine irano-aryen }\end{array} \\ & \text { Volume } \mathbf{2 7} \mid \mathbf{2 0 0 6} \\ & \text { Comptes rendus des publications de } \mathbf{2 0 0 4}\end{array}$

\title{
Medieval Islamic Political Thought. Edinburgh, Edinburgh University Press, 2004.
}

Antoine Borrut

\section{(2) OpenEdition}

1 Journals

Édition électronique

URL : http://journals.openedition.org/abstractairanica/6181

DOI : 10.4000/abstractairanica.6181

ISSN : 1961-960X

Éditeur :

CNRS (UMR 7528 Mondes iraniens et indiens), Éditions de l'IFRI

Édition imprimée

Date de publication : 15 mai 2006

ISSN : 0240-8910

Référence électronique

Antoine Borrut, "Medieval Islamic Political Thought. Edinburgh, Edinburgh University Press, 2004. », Abstracta Iranica [En ligne], Volume 27 | 2006, document 259, mis en ligne le 02 janvier 2007, consulté le 25 septembre 2020. URL : http://journals.openedition.org/abstractairanica/6181 ; DOI : https:// doi.org/10.4000/abstractairanica.6181

Ce document a été généré automatiquement le 25 septembre 2020.

Tous droits réservés 


\title{
Medieval Islamic Political Thought. Edinburgh, Edinburgh University Press, 2004.
}

\author{
Antoine Borrut
}

1 P. Crone livre un ouvrage volumineux, traitant de l'évolution de la pensée politique au cours des six premiers siècles de l'hégire, et apporte une importante contribution en matière d'analyse de la conception des pouvoirs dans l'islam médiéval.

2 L'A. met en évidence l'assimilation initiale de trois sphères, celles de la religion, de l'État et de la société ; c'est une religion nouvelle, l'islam, qui a engendré ces deux autres entités. Mais ces trois cercles se séparent progressivement au cours de la période étudiée. C'est en particulier la sphère du gouvernement qui se dissocie graduellement des deux autres, les chevauchements entre religieux et société demeurant très prégnants, en particulier en contexte urbain.

3 L'ouvrage se divise en quatre parties, les trois premières chronologiques, la dernière thématique : «les commencements " période de fusion du politique et du religieux au cours du premier siècle hégirien; «le déclin de la tradition tribale, v. 700-900", qui marque l'inexorable éclatement de cette unité première et le développement de conceptions concurrentes du pouvoir (kharijite, mu'tazilite...); « affronter un monde fragmenté », qui examine en particulier l'apport des traditions persanes et grecques dans la réflexion politique, en soulignant le rôle majeur que jouèrent alors les philosophes ismaéliens et sunnites; "gouvernement et société ", qui discute enfin plusieurs notions essentielles (nature et fonctions du gouvernement, ordre social...).

4 On soulignera enfin la qualité des tableaux proposés en annexe, qui éclairent notamment les différentes conceptions de la umma par les omeyyades et les chiites, ainsi que l'utilité de l'index remplissant aussi la fonction de glossaire. 
INDEX

Thèmes : 7. Islam

\section{AUTEURS}

ANTOINE BORRUT

IFPO - Damas 